\title{
PENGARUH PENAMBAHAN POLIFENOL TERHADAP KARAKTERISTIK MILK CHOCOLATE COUVERTURE DAN ANALOG
}

\author{
The Effect of Polyphenol Addition to Milk Chocolate Couverture \\ and Analog Characteristics
}

\author{
Dyah Wuri Asriati, Imran Thamrin, Melia Ariyanti, dan Ardiansyah \\ Balai Besar Industri Hasil Perkebunan \\ Jl. Prof. Dr. H. Abdurahman Basalamah No.28 Makassar \\ e-mail : dyahw_asriati@yahoo.com
}

\begin{abstract}
The effect of polyphenols addition in milk chocolate couverture and analog has been carried out. This study aims to determine the effect of polyphenols addition to milk couverture chocolate and analog. The research stages consisted of fermented and unfermented cocoa beans roasting, cocoa bean shell addition, grinding, product formulation with polyphenols addition, mixed by conching, tempering for milk chocolate couverture, while it directly moulded and packaged. Parameters analyzed included water and fat content, viscosity, melting point, and ALT. While organoleptic tests included flavour, taste, texture, and product appearance. The results showed that polyphenols addition can increase the value of viscosity (918000-1280000 Cp), increase the melting point of product $\left(30-33^{\circ} \mathrm{C}\right)$, total fat $(41.88-42.89 \%)$, moisture content (1.25-1.52\%), ALT (100-240 colonies/g) according to SNI 4458-1998 and preferred by panelists with a score range of 3.30-3.57 (quite like) for milk chocolate couventure with polyphenols addition to enhance the chocolate flavour, taste, texture and appearance.
\end{abstract}

Keywords: characteristics, milk chocolate, organoleptic, polyphenols

\begin{abstract}
ABSTRAK: Telah dilakukan penelitian pengaruh penambahan polifenol pada pembuatan produk milk chocolate couverture dan analog. Penelitian ini bertujuan untuk mengetahui pengaruh penambahan polifenol terhadap karakteristik milk chocolate couverture dan analog. Tahapan penelitian terdiri dari penyangraian biji kakao fermentasi dan tanpa fermentasi, pemisahan kulit ari biji kakao, pemastaan, formulasi produk dengan penambahan polifenol, pencampuran dengan conching, tempering untuk milk chocolate couverture, dan langsung pencetakan dan pengemasan untuk milk chocolate analog. Parameter yang dianalisa meliputi kadar air, kadar lemak, viskositas, titik leleh, dan ALT. Sedangkan uji organoleptik meliputi aroma, rasa, tekstur, dan penampakan produk. Hasil penelitian menunjukkan bahwa penambahan polifenol pada produk dapat meningkatkan nilai viskositas (918000-1280000 Cp), menaikkan titik leleh produk (30-33 $\mathrm{C})$, total lemak (41,88-42,89\%), kadar air (1,25-1,52\%), ALT (100-240 koloni/g) sesuai SNI 4458-1998, dan disukai oleh panelis dengan rentang skor 3,303,57 (cukup suka) untuk produk milk chocolate couventure dan analog dengan penambahan polifenol sebagai penambah aroma, rasa, tekstur, dan penampakan cokelat.
\end{abstract}

Kata kunci: karakteristik, milk chocolate, organoleptik, polifenol

\section{PENDAHULUAN}

Cokelat merupakan suspensi partikel-partikel seperti pasta kakao, susu bubuk, dan gula yang terdispersi dalam fase kontinyu, yaitu lemak kakao (Andrae-Nightingale et al., 2009). Kualitas produk cokelat dipengaruhi oleh struktur, teknik proses, dan komposisi bahan (Jovanovic et al., 2002). Produk cokelat memiliki potensi yang sangat besar untuk berkembang di Indonesia. Saat ini, produk cokelat merupakan kategori cemilan terfavorit ke 4 setelah pastry, biskuit, dan permen dengan nilai pasar hingga US\$ 776 juta atau setara dengan Rp. 11,2 trilliun (Richard, 2018)

Berdasarkan jenis lemak yang digunakan, produk cokelat yang beredar di pasaran ada 2 macam, yaitu cokelat couverture (kovertur) dan cokelat compound. Cokelat couverture diolah dari kakao massa dan lemak kakao, sedangkan cokelat compound dari kakao bubuk dan lemak substitusi. Salah satu kelemahan produk cokelat couverture, khususnya untuk pemasaran dan konsumsi di daerah 
tropis, adalah melelehnya fraksi lemak sehingga tekstur dan kenampakan menjadi kurang menarik dan sering diikuti dengan terjadinya blooming. Fraksi lemak dalam cokelat sangat menentukan tekstur, kenampakan, penanganan proses, penyimpanan, dan distribusinya. Sulistyowati dan Misnawi (2008) menyebutkan bahwa kekerasan cokelat merupakan parameter kualitas yang penting, khususnya untuk distribusinya pada daerah tropis. Cokelat memiliki sifat leleh yang unik, yaitu bersifat padat pada suhu ruang dan meleleh pada suhu tubuh (Afoakwa, 2010).

Karakteristik produk cokelat meliputi rasa yang khas dan tekstur yang lembut. Rasa dan tekstur produk cokelat sangat ditentukan oleh formulasi dan kehalusan partikel sehingga kedua faktor ini sangat mempengaruhi sifat reologi dari cokelat yang dihasilkan (Indarti et al., 2012). Selain itu, proses dalam pembuatan cokelat mempengaruhi kualitas akhir produk cokelat dan salah satu tahapan proses pembuatan cokelat adalah conching. Afoakwa et al. (2007) menyatakan bahwa conching merupakan tahap yang penting untuk menentukan ukuran partikel dan konsistensi suspensi dan viskositas untuk menghasilkan kualitas tekstur dan sensori yang khas.

Senyawa polifenol merupakan senyawa kimia yang mempunyai sifat antioksidan yang sangat penting peranannya dalam menyehatkan tubuh manusia (Jalil dan Ismail, 2008; Nestle Research Centers, 2010; Crozier et al., 2011). Kandungan senyawa polifenol pada produk cokelat sangat berkontribusi untuk menyehatkan tubuh karena mempunyai peran sebagai antioksidan, antikanker, antidiabetes, antihipertensi, antiinflamansi, menghilangkan stres, mencegah karies gigi, meningkatkan kemampuan kognitif, meningkatkan resistensi terhadap hemolisis, menyehatkan jantung, dan sebagai aprodisiak (Kelishadi, 2005; Afoakwa, 2008; Watson et al., 2012; Ackar et al., 2013).
Persyaratan mutu tambahan dari produk kakao yang diinginkan oleh industri makanan dan minuman di Indonesia adalah mutu organoleptik, yaitu citarasa dan aroma khas cokelat yang menonjol serta rasa asam rendah. Citarasa dan aroma khas cokelat akan berkembang lebih sempurna pada biji kakao yang telah mengalami proses fermentasi sempurna. Prekursor citarasa yang berupa asam amino, peptida, dan gula pereduksi akan membentuk komponen citarasa di bawah reaksi Maillard (reaksi pencoklatan nonenzimatis) selama penyangraian. Fermentasi biji kakao akan menghasilkan prekursor citarasa, menghasilkan warna biji yang cokelat kehitaman, mengurangi rasa pahit, asam, manis, dan aroma bunga, meningkatkan aroma kakao dan kacang (nutty), dan mengeraskan kulit biji menjadi seperti tempurung. Biji yang tidak difermentasi tidak akan memiliki senyawa prekursor tersebut sehingga cita rasa dan mutu biji sangat rendah.

Mengingat berbagai manfaat penting senyawa polifenol yang terkandung pada biji kakao maupun produk turunannya bagi kesehatan tubuh manusia, maka penggunaan bahan baku dari biji kakao tanpa fermentasi dan dengan fermentasi serta adanya penambahan polifenol kakao yang dicampurkan ke dalam adonan cokelat diujicoba dalam proses pengolahan sehingga produk akhir tetap kaya akan kandungan polifenol yang menyehatkan. Tujuan dari penelitian ini adalah untuk mengetahui pengaruh penambahan polifenol terhadap karakteristik produk milk chocolate couverture dan analog.

\section{METODOLOGI Bahan dan Alat}

Bahan baku yang digunakan untuk pembuatan milk chocolate couverture adalah biji kakao kering fermentasi (fermented) dan bahan baku yang digunakan untuk pembuatan milk chocolate analog adalah biji kakao kering tanpa fermentasi (unfermented) yang berasal dari Kab. Polman Provinsi 
Sulawesi Barat, Cocoa Butter Substitute dari salah satu IKM di Jakarta, lemak kakao dari PT. Mars Symbioscience Indonesia di Makassar, flavor cokelat, susu full cream, garam, dan lesitin.

Alat pengolahan yang digunakan adalah alat roasting, alat winnowing, alat pemasta, alat conching, dan alat cetak cokelat.

\section{Metode Penelitian}

Proses pembuatan milk chocolate couverture dan analog merupakan modifikasi dari proses yang sudah ada. Biji kakao kering fermentasi dan tanpa fermentasi disangrai (roasting) pada suhu $120^{\circ} \mathrm{C}$ selama 40 menit, kemudian masing-masing dipisahkan kulit ari dan nibnya menggunakan alat winnowing. Nib kakao tersebut dihaluskan menggunakan grinder machine.
Selanjutnya, pasta kakao dicampur dengan Cocoa Butter Substitute untuk milk chocolate analog dan lemak kakao untuk milk chocolate couverture sesuai formula yang tertera pada Tabel 1 . Setelah itu ditambahkan ekstrak polifenol dari biji non fermentasi, susu full cream, garam, lesitin, dan flavor cokelat ke dalam alat conching. Proses conching dilakukan pada suhu $50^{\circ} \mathrm{C}$ selama 7 jam. Setelah proses conching selesai, dilakukan proses tempering untuk milk chocolate couverture sebelum proses pencetakan, sedangkan milk chocolate analog langsung dilakukan proses pencetakan. Setelah pencetakan, masing-masing produk dikemas menggunakan aluminium foil. Formula yang digunakan pada pembuatan milk chocolate adalah modifikasi formula dasar yang mengacu pada Becket (2009).

Tabel 1. Formula Milk Chocolate Couverture dan Analog

\begin{tabular}{lcccc}
\hline \multirow{2}{*}{ Perlakuan } & \multicolumn{2}{c}{ Milk Chocolate Couverture } & \multicolumn{2}{c}{ Milk Chocolate Analog } \\
\cline { 2 - 5 } & RCKT (\%) & RCAOT $(\%)$ & $\begin{array}{c}\text { RCAOP } \\
(\%)\end{array}$ & RCKP (\%) \\
\hline $\begin{array}{l}\text { Cocoa Liquor } \\
\text { (fermented) }\end{array}$ & 25 & - & - & 25 \\
\hline $\begin{array}{l}\text { Cocoa Liquor } \\
\text { (unfermented) }\end{array}$ & - & 25 & 25 & - \\
\hline Lemak Kakao & 25 & - & - & 25 \\
\hline CBS & - & 25 & 0,2 & - \\
\hline Polifenol & - & - & 30,4 & 30,4 \\
\hline Sukrosa & 30,4 & 30,4 & 19 & 19 \\
\hline Susu full cream & 19 & 19 & 0,3 & 0,3 \\
\hline Lesitin & 0,3 & 0,3 & 0,1 & 0,1 \\
\hline Garam & 0,1 & 0,1 & 0,2 & 0,2 \\
\hline Perisa Cokelat & 0,2 & 0,2 & & \\
\hline
\end{tabular}

Ket. :

RCKT : Milk chocolate couverture tanpa polifenol

RCKP : Milk chocolate couverture dengan penambahan polifenol

RCAOT : Milk chocolate analog tanpa polifenol

RCAOP : Milk chocolate analog dengan penambahan polifenol 


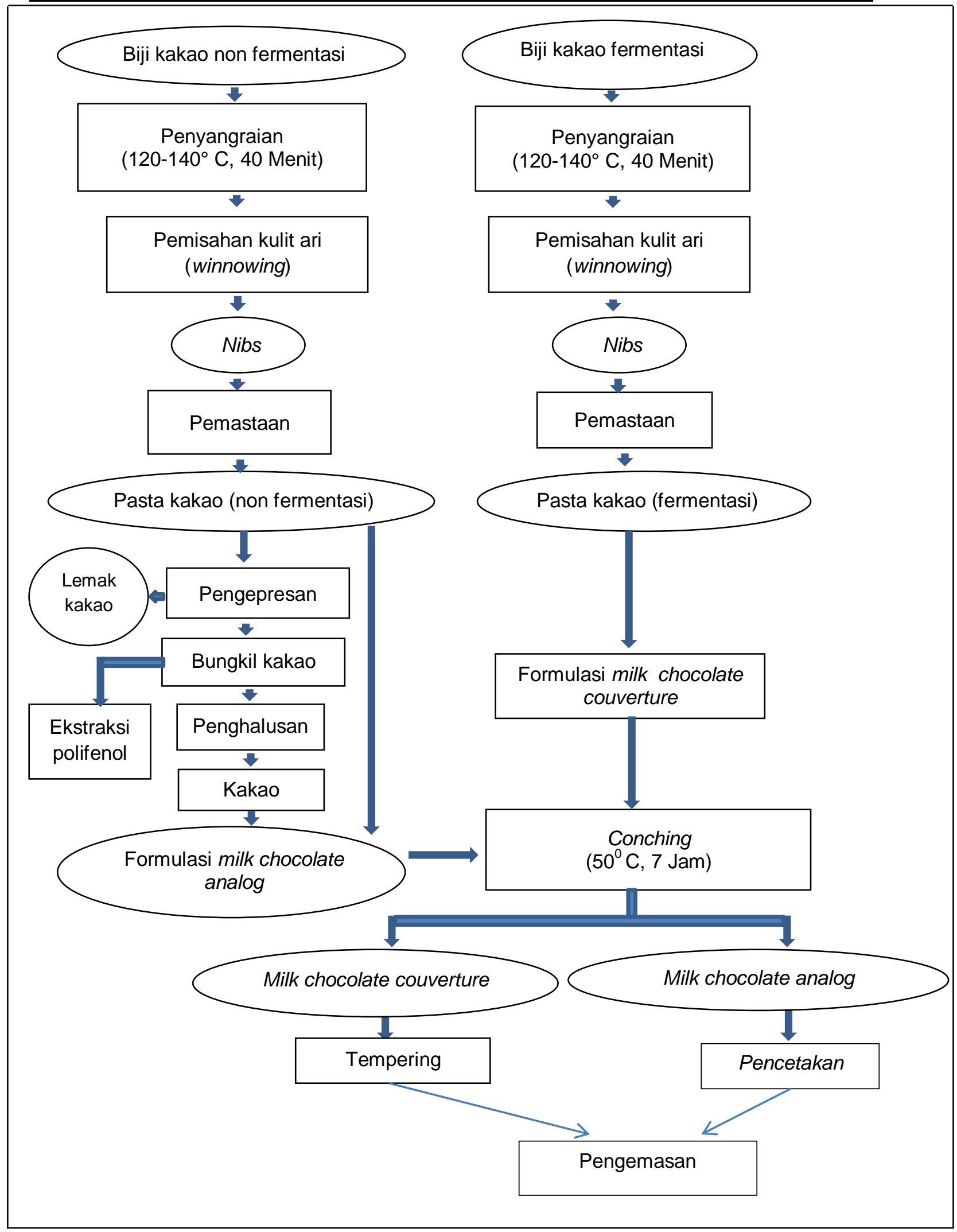

Gambar 1. Diagram Alir Penelitian Pembuatan Milk Chocolate Couventure dan Analog 
Uji organoleptik dilakukan untuk mengetahui tingkat kesukaan panelis terhadap pengaruh penambahan polifenol pada produk. Panelis uji terdiri dari 23 orang yang sebelumnya telah dikenalkan kepada citarasa dan mutu dasar cokelat. Panelis memberikan penilaian berdasarkan tingkat kesukaannya terhadap 4 sampel yang disediakan. Sampel uji meliputi milk chocolate couverture dan analog dengan penambahan dan tanpa penambahan polifenol. Panelis mengisi kuesioner berdasarkan tingkat penerimaan dengan Hedonic Scale sebagai berikut: 5 (sangat suka), 4 (suka), 3 (cukup suka), 2 (kurang suka), dan 1 (tidak suka) (Soekarto, 1985).

\section{Metode Analisis}

Analisis terhadap karakteristik milk cokelat couverture dan analog dengan penambahan polifenol dan tanpa penambahan polifenol meliputi uji viskositas menggunakan metode pengukuran viskometer, uji kadar lemak menggunakan metode Kjedhal, uji kadar air menggunakan metode oven, uji titik leleh menggunakan metode WRS200, dan uji ALT menggunakan metode Plate Count. Uji organoleptik dilakukan terhadap produk cokelat meliputi aroma, rasa, tekstur, dan penampakan menggunakan metode Hedonic Scale (tingkat kesukaan) menurut Soekarto (1985) serta analisis data hasil uji.

Penelitian ini menggunakan analisis data secara deskriptif. Analisis data secara deskriptif merupakan teknik analisis yang digunakan dalam menganalisis data dengan membuat gambaran data-data yang terkumpul tanpa membuat generalisasi dari hasil penelitian tersebut. Data hasil uji laboratorium pada penelitian ini disajikan dalam bentuk tabel dan diagram yang selanjutnya dianalisis secara deskriptif.
HASIL DAN PEMBAHASAN

Produk milk chocolate analog hasil penelitian mengandung polifenol yang cukup tinggi karena menggunakan biji kakao nonfermentasi dan adanya ekstrak polifenol yang ditambahkan ke dalam produk cokelat. Menurut Harrington (2011), adanya kandungan senyawa polifenol dalam produk cokelat akan memberikan keuntungan bagi peningkatan kualitas produk tersebut karena senyawa polifenol mempunyai kemampuan antioksidan yang dapat mencegah terjadinya kerusakan makanan akibat oksidasi terhadap lemak kakao yang dapat menyebabkan ketengikan (rancidity). Sehingga akan meningkatkan keawetan maupun waktu simpan dari produk makanan cokelat tersebut.

\section{Viskositas}

Viskositas dapat digambarkan seperti terasa adanya perlawanan pada saat pengadukan cairan. Cokelat dengan viskositas rendah mudah untuk dipompa. Viskositas bergantung pada suhu dan juga dipengaruhi oleh beberapa faktor seperti kadar lemak, kuantitas lesitin, kadar air, distribusi ukuran partikel, dan waktu conching.

Dari Gambar 2 terlihat bahwa produk cokelat couverture baik dengan penambahan polifenol maupun tanpa penambahan mempunyai viskositas $9,18 \times 10^{5} \mathrm{Cp}$ dan $8,2 \times 10^{5} \mathrm{cP}$, lebih cair dibanding produk cokelat analog dengan penambahan polifenol maupun tanpa penambahan. $\mathrm{Hal}$ ini menunjukkan bahwa penambahan polifenol dapat meningkatkan viskositas produk cokelat secara keseluruhan. Terjadinya peningkatan viskositas pada produk cokelat disebabkan oleh penggunaan ekstrak polifenol yang mengandung tambahan maltodekstrin sebanyak $10 \%$ sebagai penyalut pada saat dikeringkan menggunakan spray dryer. Maltodekstrin memiliki karakteristik viskositas yang tinggi, namun stabilitas, kelarutan, dan laju absorpsinya amat rendah (Kearsley and Ziedzic, 1995). 


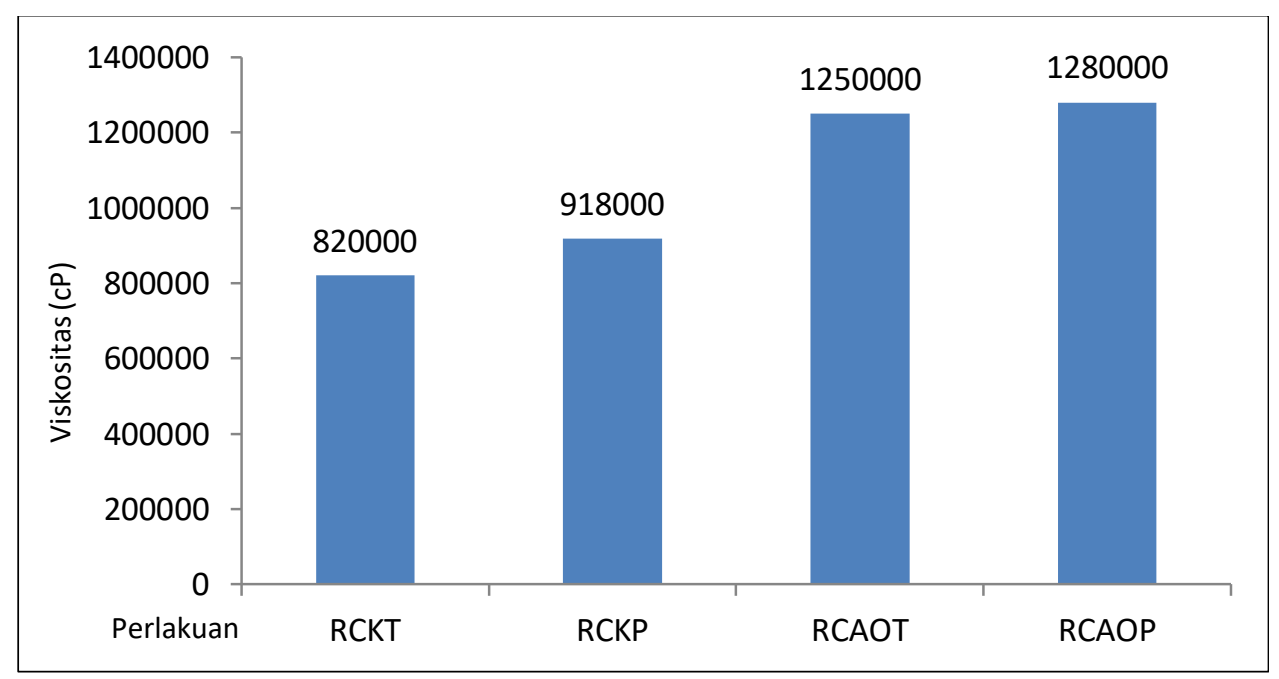

Gambar 2. Nilai Viskositas Milk Chocolate Couverture dan Analog

Penambahan pengemulsi lesitin juga mempengaruhi penurunan nilai viskositas. Hal ini sesuai dengan yang dinyatakan Akra et al. (2012) bahwa penambahan pengemulsi sangat mempengaruhi perubahan viskositas bahan (cokelat). Jenis dan jumlah pengemulsi mempengaruhi reologi. Lesitin yang ditambahkan dalam persentase $0,1-0,3 \%$ memiliki efek penurunan viskositas yang serupa dengan yang dicapai jika menambahkan 1-3\% lemak kakao. Johansson dan Bergenstahl dalam Tisoncik (2010) menyatakan bahwa emulsifier berperan terhadap sifat alir cokelat dan kristalisasi lemak kakao.

Perbedaan nilai viskositas yang dihasilkan dipengaruhi oleh kecepatan putar spindle pada alat viskometer. Meningkatnya putaran menyebabkan naiknya tekanan pada produk sehingga ukuran produk milk chocolate couverture semakin kecil atau semakin bersifat cair atau encer.

\section{Titik Leleh}

Titik leleh lemak kakao yang baik untuk makanan cokelat adalah mendekati suhu badan manusia dengan tingkat kekerasan minimum pada suhu kamar. Titik leleh lemak merupakan salah satu penentu utama tekstur dan kekerasan cokelat. Cokelat yang baik adalah cokelat yang tidak mencair pada suhu ruang tetapi meleleh ketika berada di dalam mulut sehingga memberikan mood feeling yang lembut. Grafik hasil analisis titik leleh produk milk chocolate dapat dilihat pada Gambar 3.

Komponen penyusun cokelat yang paling menentukan karakteristik meleleh pada produk cokelat adalah lemak kakao. Dalam lemak kakao, asam lemak penyusun utamanya terdiri atas $33,2-37,4 \%$ asam oleat (C18:1), $32,9-37,1 \%$ asam stearat (C18:0), dan 23,7-25,5\% asam palmitat (C16:0). Asam palmitat dan asam stearat merupakan asam lemak jenuh dimana keduanya tidak mengandung ikatan rangkap, sedangkan asam oleat merupakan asam lemak tidak jenuh dengan satu ikatan rangkap. Karena sebagian besar asam lemak penyusunnya relatif tidak bervariasi, maka lemak kakao memiliki sifat fisik unik, yaitu cepat meleleh pada kisaran suhu yang tidak terlalu jauh antara suhu ruang $\left(30^{\circ} \mathrm{C}\right)$ dengan suhu mulut (suhu tubuh) sekitar $34^{\circ} \mathrm{C}$ (Afoakwa, 2010).

Pangerang (2012) menyatakan bahwa semakin banyak lemak kakao yang ditambahkan, semakin rendah titik leleh dari produk yang dihasilkan. Chocolate couverture lebih mudah meleleh karena mengandung cocoa butter. Penambahan lemak kakao 
dalam jumlah banyak menyebabkan cokelat mudah meleleh. Meningkatnya titik leleh menyebabkan terjadinya peningkatan kestabilan produk cokelat sehingga tidak mudah meleleh pada suhu kamar.

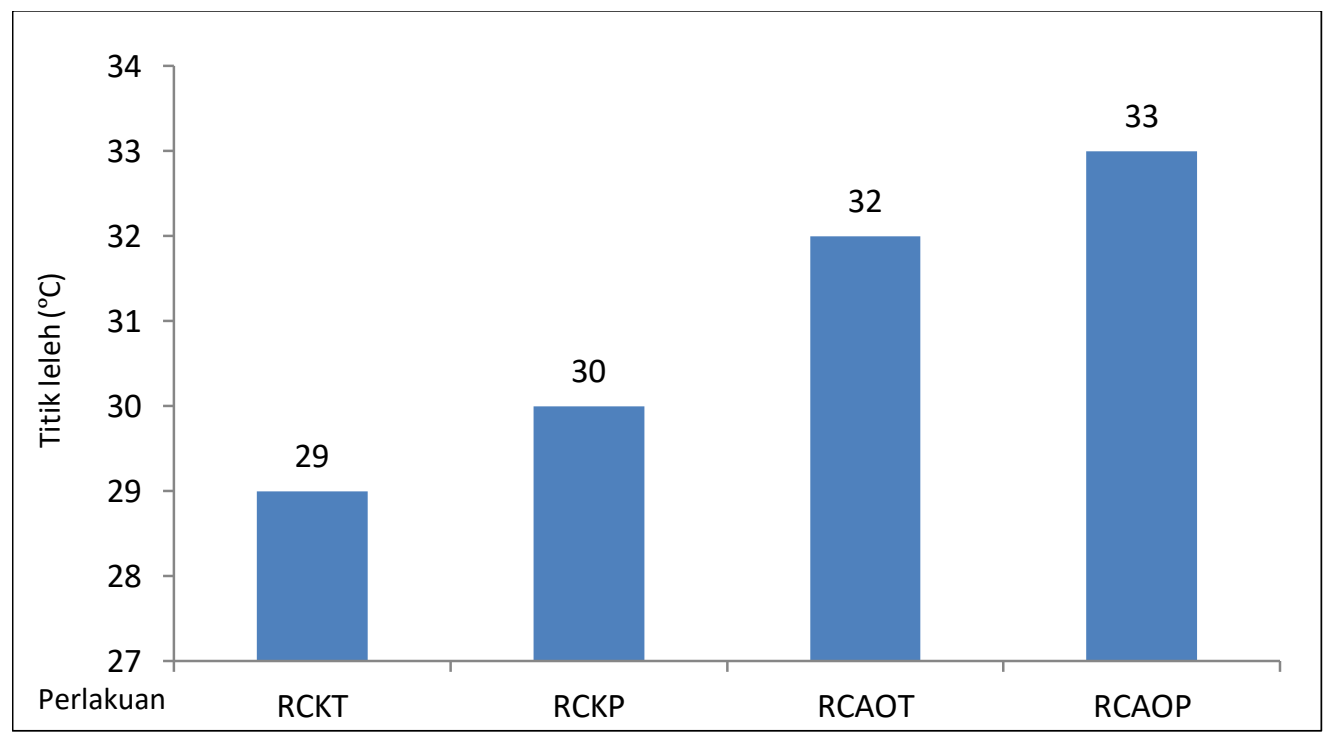

Gambar 3. Titik Leleh Milk Chocolate Couverture dan Analog

\section{Total Lemak}

Hasil analisis total lemak pada milk chocolate couverture dan analog dapat dilihat pada Gambar 4. Kadar lemak milk chocolate couverture berada pada kisaran 42,89-43,04\%, dan kadar lemak milk chocolate analog berada pada kisaran 40,96-41,88\% (Gambar 4). Hal ini disebabkan oleh penggunaan bahan baku cocoa liquor (25\%) dalam adonan milk chocolate couverture, dimana cocoa liquor mengandung lemak sekitar $50 \%$, sedangkan milk chocolate analog menggunakan bahan baku campuran cocoa liquor $(15 \%)$ dan kakao bubuk (10\%) sehingga kadar lemak produk cokelat analog sedikit lebih rendah daripada cokelat couverture. Kandungan lemak pada milk chocolate analog tanpa penambahan polifenol sebesar 40,96\% lebih rendah dibandingkan dengan penambahan polifenol sebesar $41,88 \%$. Namun demikian, semua produk cokelat susu (milk chocolate) yang dihasilkan pada penelitian ini memenuhi syarat untuk parameter total lemak. Persyaratan kandungan total lemak pada SNI pasta cokelat (SNI 4458-1998) lebih besar dari 31\%.

Kandungan total lemak pada produk juga diperoleh dari penggunaan susu bubuk full cream yang mengandung lemak sekitar $11 \%$. Selain itu, selama pengolahan terjadi penurunan kadar air sehingga menyebabkan persentase komponen penyusun lain dari produk yang tidak larut meningkat (Ramlah dan Sampebarra, 2018). Penambahan polifenol pada proses pembuatan milk chocolate couverture dan analog tidak berpengaruh secara signifikan terhadap kandungan total lemak produk. Pada milk chocolate couverture, penambahan polifenol sedikit menurunkan kandungan total lemak, sedangkan penambahan polifenol pada milk chocolate analog malah meningkatkan total lemak. Perbedaan kandungan total lemak yang terdapat pada kedua produk cokelat tersebut diakibatkan adanya penggunaan sumber lemak yang berbeda dan bahan penyusun produk yang berbeda. 


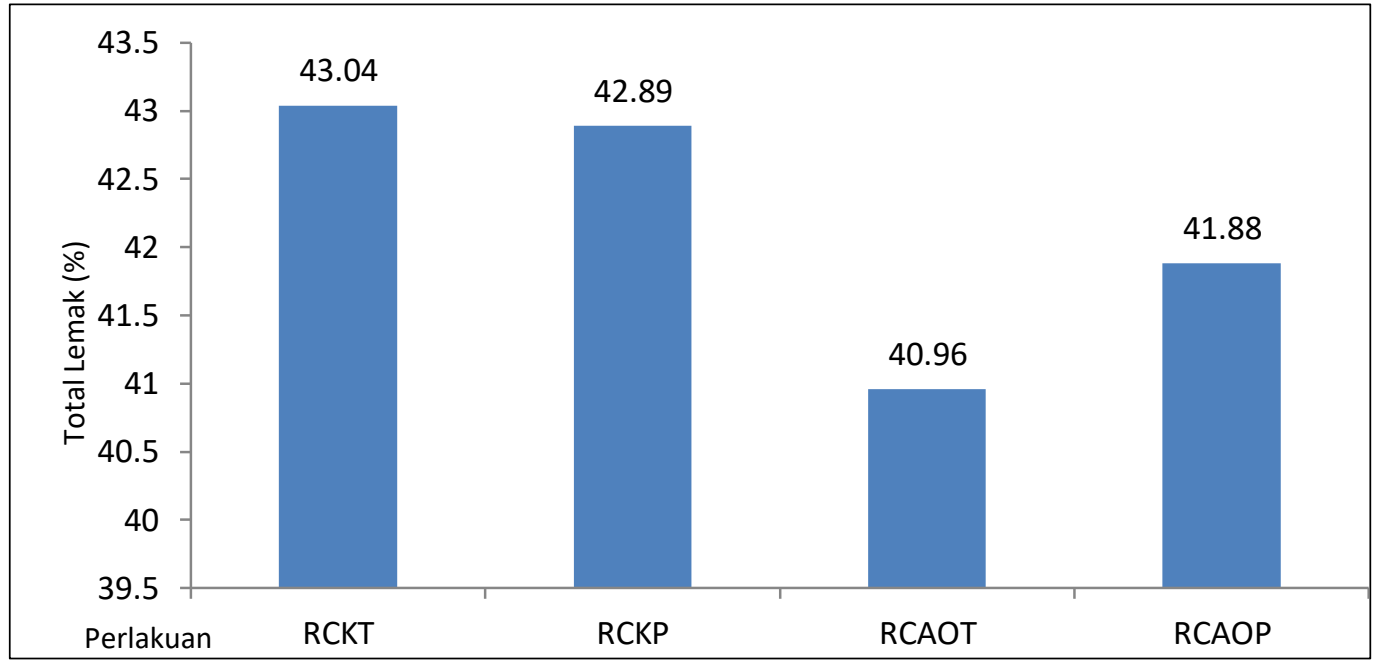

Gambar 4. Total Lemak Milk Chocolate Couverture dan Analog

\section{Kadar Air}

Kadar air merupakan banyaknya air yang terkandung di dalam suatu bahan yang dinyatakan dalam persen (\%). Kadar air juga merupakan salah satu karakteristik yang sangat penting pada bahan karena dapat mempengaruhi penampakan, tekstur, dan citarasa pada bahan pangan (Winarno, 1993). Hasil analisis kandungan kadar air dapat dilihat pada Gambar 5.

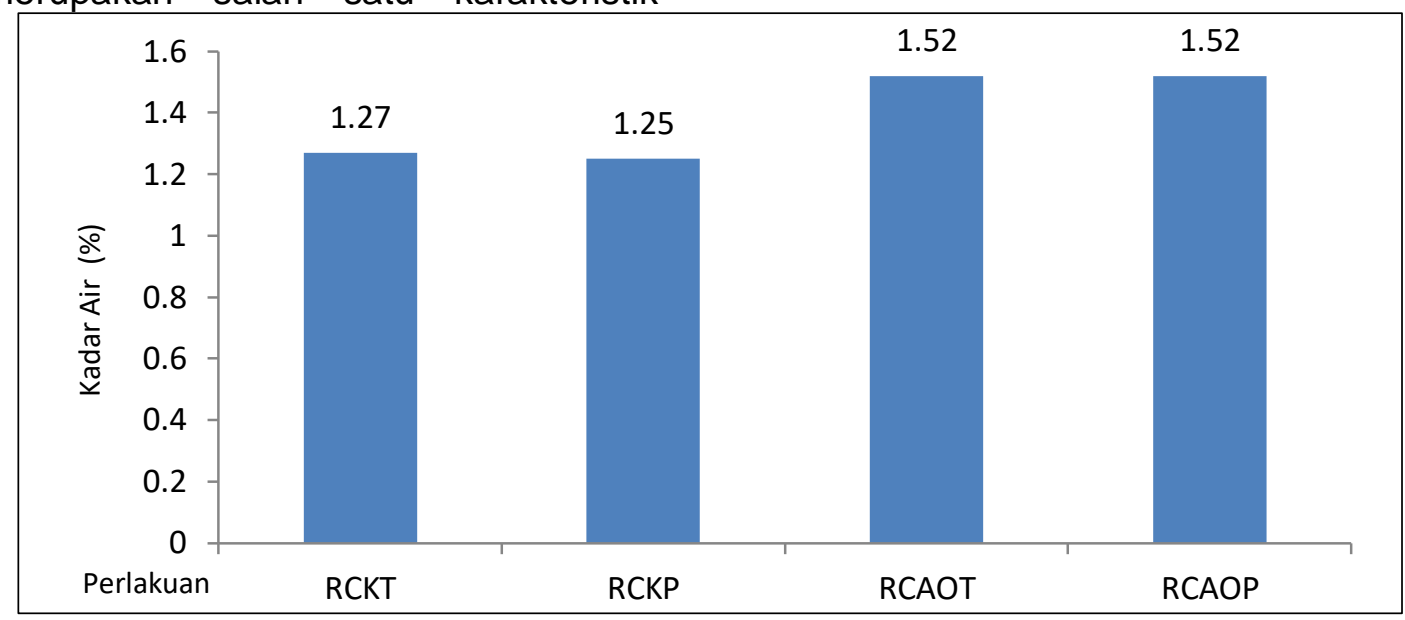

Gambar 5. Kadar Air Milk Chocolate Couverture dan Analog

Gambar 5 menunjukkan bahwa secara umum kandungan kadar air milk chocolate analog lebih tinggi daripada milk chocolate couverture. Hal ini terjadi karena ada perbedaan proses pengolahan pada cokelat couverture dengan analog yaitu dilakukannya tempering terlebih dahulu sebelum pencetakan. Proses tempering menggunakan alat tempering yang otomatis menyetel suhu untuk milk chocolate couverture pada suhu $31^{\circ} \mathrm{C}$ sebelum siap cetak sehingga dapat mengurangi kadar air produk. Pada umumnya, kadar air produk yang dihasilkan dari penelitian ini dipengaruhi oleh kandungan air dari bahan baku dan bahan tambahan yang digunakan serta proses pengolahan produk yang digunakan.

Penambahan polifenol tidak memberikan pengaruh terhadap kandungan kadar air milk chocolate. Dalam SNI cokelat dan produk cokelat (SNI 7934-2014), tidak dipersyaratkan parameter kadar air, namun dalam SNI pasta cokelat (SNI 4458-1998) diketahui bahwa kadar air 
maksimumnya adalah 2,0\%. Jika merujuk ke SNI pasta cokelat maka semua produk cokelat yang dibuat pada penelitian ini telah memenuhi syarat.
Angka Lempeng Total (ALT)

Hasil analisis kandungan Angka Lempeng Total (ALT) pada produk milk chocolate couverture dan analog dapat dilihat pada Gambar 6.

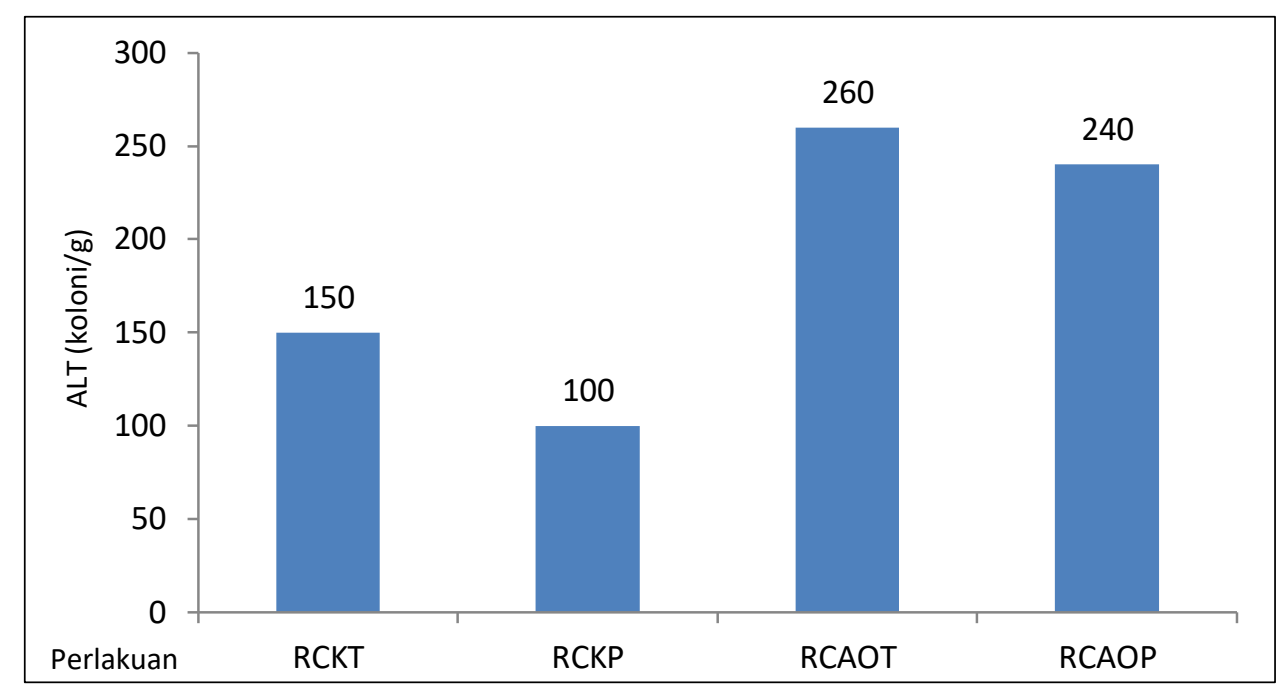

Gambar 6. Angka Lempeng Total pada Milk Chocolate Couverture dan Analog

Persyaratan ALT dalam SNI cokelat dan produk cokelat (SNI 44581998) adalah maksimum $1 \times 10^{4}$ koloni/g. Hal ini mengartikan bahwa semua produk cokelat yang dihasilkan pada penelitian ini telah memenuhi syarat untuk parameter ALT. Tinggi rendahnya nilai ALT pada semua produk cokelat dipengaruhi oleh berbagai faktor, antara lain faktor higienitas ruang pengolahan, peralatan, dan lain-lain. Ramlah dan Yumas (2017) mengemukakan bahwa cemaran mikroba, termasuk angka lempeng total pada suatu produk dipengaruhi oleh beberapa hal, diantaranya adalah bahan baku dan peralatan yang digunakan serta proses pengolahannya.

Gambar 6 menunjukkan bahwa ALT pada produk RCKT dan RCAOT mengandung mikroba lebih banyak dibandingkan dengan produk RCKP. Rendahnya jumlah mikroba yang terdapat pada produk RCKP karena adanya penambahan polifenol, dimana salah satu fungsi dari polifenol adalah sebagai antimikroba yang menghambat laju pertambahan mikroba. $\mathrm{Hal}$ ini sesuai dengan yang dikemukakan oleh
Ardiansyah (2007) bahwa gugus fenol dan gugus hidroksil dari golongan senyawa polifenol atau flavonoid yang terkandung di dalam buah kakao dapat digunakan sebagai bahan pengawet alami. Senyawa ini berperan sebagai pengawet karena gugus hidroksilnya mampu mengikis radikal bebas, sedangkan gugus fenolnya dapat menonaktifkan atau menghambat aktivitas bakteri. Berbanding terbalik dengan produk RCAOP jumlah mikroba yang terdapat pada produk RCKT lebih sedikit (Gambar 6). Hal ini diakibatkan karena produk RCAOP mengandung air lebih banyak dibandingkan produk RCKT (Gambar 5) sehingga konsentrasi polifenol pada produk RCAOP mengalami pengenceran. Selain itu,air merupakan salah satu media tempat tumbuhnya mikroba. Hal ini sesuai dengan yang dikemukakan oleh Aditya dan Ariyanti (2016) bahwa kadar air dalam bahan pangan ikut menentukan kesegaran dan daya awet bahan pangan. Kadar air yang tinggi dapat mengakibatkan mudahnya pertumbuhan bakteri, kapang, dan khamir sehingga berefek terhadap kerusakan bahan pangan. 
Uji Organoleptik

Hasil uji organoleptik (aroma, rasa, tekstur, dan penampakan) produk milk chocolate couverture dan analog dapat dilihat pada Tabel 3.

Tabel 3. Hasil Organoleptik Milk Chocolate Couverture dan Analog

\begin{tabular}{ccccc}
\hline Kode Perlakuan & \multicolumn{4}{c}{ Nilai Organoleptik } \\
\cline { 2 - 5 } & Aroma & Rasa & Tekstur & Penampakan \\
\hline RCKT & 3,04 & 3,09 & 2,61 & 2,53 \\
\hline RCKP & 3,35 & 3,35 & 3,30 & 3,13 \\
\hline RCAOT & 3,17 & 3,04 & 2,96 & 3,30 \\
\hline RCAOP & 3,48 & 3,57 & 3,26 & 3,57 \\
\hline
\end{tabular}

\section{Aroma}

Aroma merupakan salah satu faktor terpenting bagi konsumen dalam memilih produk makanan yang disukai. Winarno (1997) mengatakan bahwa kelezatan makanan ditentukan oleh aroma atau bau dari makanan tersebut.

Aroma produk cokelat (Tabel 3), baik cokelat couverture maupun cokelat analog, pada umumnya, panelis memberikan penilaian dengan skor 3,04-3,48 (cukup suka). Aroma produk cokelat walaupun menggunakan biji kakao nonfermentasi pada cokelat analog tetapi aroma khas cokelat cukup disukai panelis karena adanya penambahan flavor khas cokelat sebanyak $0,2 \%$ ke dalam adonan cokelat.

Pada kakao, terdapat beberapa golongan senyawa yang penting dalam pembentukan aroma. Menurut Maarse (1991), beberapa senyawa yang berperan dalam pembentukan aroma kakao antara lain senyawa-senyawa hidrokarbon, alkohol, aldehida, keton, asam karboksilat, ester, furan, fenol dan eter, pirol (pyrroles), oxazoles, thiazoles, piridin (pyridine) dan quinolines, pirazin, amina, komponenkomponen bersenyawa nitrogen serta komponen bersenyawa belerang.

\section{Rasa}

Paramater sensori rasa dapat dievaluasi dengan analisis deskripsi ataupun penerimaan konsumen. Rasa adalah hal yang terpenting pada sifat organoleptik suatu produk. Salah satu bahan yang mempengaruhi rasa pada produk adalah gula. Rasa manis adalah sifat rasa yang mempengaruhi cita rasa keseluruhan cokelat (Wahyudi, 2008). Tabel 3 menunjukkan bahwa terjadi peningkatan kesukaan panelis pada produk cokelat yang ditambahkan polifenol baik untuk rasa cokelat couverture maupun analog dengan skor 3,04-3,57 (cukup suka). Secara organoleptik, fungsi polifenol yang ditambahkan pada produk cokelat adalah menambah rasa khas cokelat. 


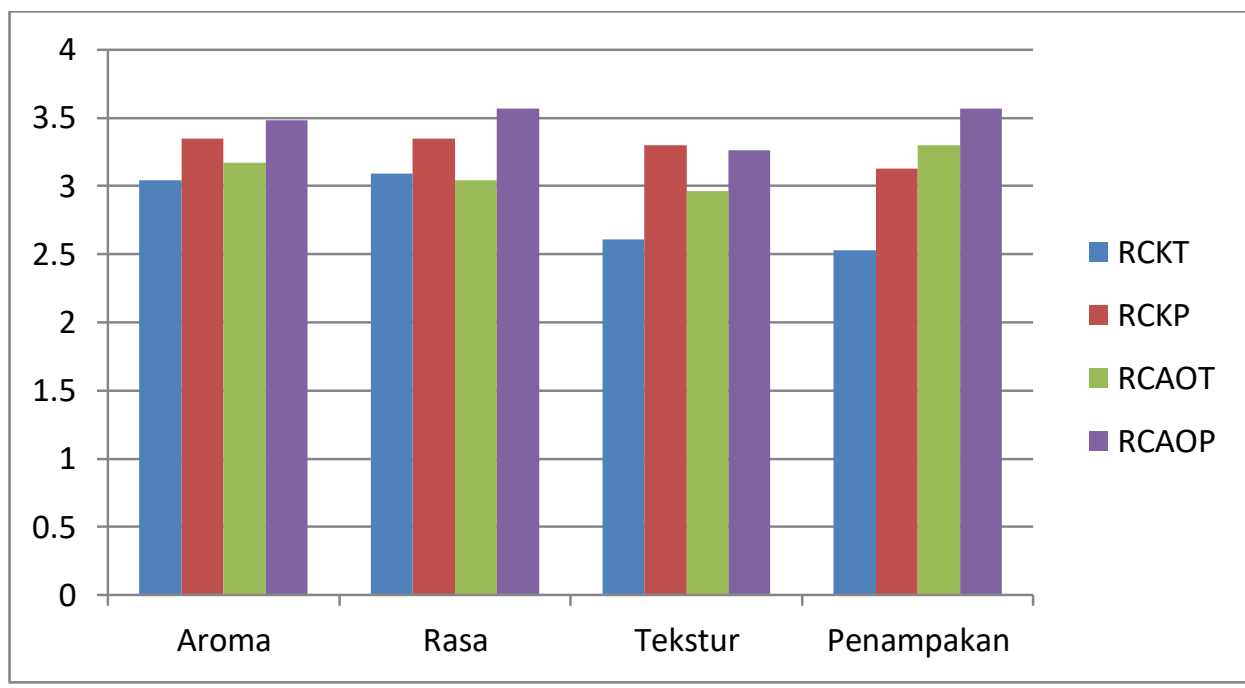

Gambar 7. Hasil Organoleptik Milk Chocolate Couverture dan Analog

\section{Tekstur}

Sifat tekstural cokelat adalah tingkat kekerasan di dalam mulut, yaitu tenaga yang dibutuhkan untuk mematahkan cokelat menggunakan gigi dan lidah. Daya leleh adalah cara cokelat meleleh sepenuhnya di dalam mulut. Kehalusan yaitu tingkat kekasaran dan berbutir (seperti berpasir) yang dirasakan di dalam mulut. Kelengketan cokelat merupakan tingkat dimana campuran cokelat leleh dan air liur menempel pada lidah dan langit-langit mulut.

Cokelat yang meleleh pada suhu tubuh mengindikasikan bahwa kemungkinan kristal lemak kakao berada dalam bentuk V. Bentuk V merupakan bentuk lemak kakao yang paling stabil dan diperoleh dari proses tempering dan memiliki titik leleh sekitar 34으 (Fernandez et al., 2013). Lemak kakao yang berada dalam bentuk $\mathrm{V}$ memiliki titik leleh sekitar suhu oral manusia, yaitu $34^{\circ} \mathrm{C}$ sehingga ketika cokelat masuk ke dalam mulut menyebabkan cokelat mulai meleleh. Afoakwa et al. (2007) menyatakan bahwa sifat organoleptik cokelat sangat bergantung pada karakteristik fase kontinyu, yaitu lemak kakao. Semakin lama proses oral cokelat berlangsung, tingkat kekerasan cokelat semakin menurun dan semakin mereduksi ukuran partikel cokelat. Ukuran partikel yang semakin kecil akan meningkatkan luas permukaan untuk transfer panas karena pecahnya formasi partikelpartikel cokelat sehingga proses pelelehan cokelat menjadi semakin signifikan.

Kekerasan cokelat tergantung pada konsentrasi fase kristalisasi lemak (lemak kakao, lemak susu), dan fase padatan terdispersi (gula, padatan susu, padatan kakao). Resep (formula), teknik produksi, tempering, polimorfisme, dan suhu pendinginan juga berpengaruh pada kekerasan cokelat padat (Abdullah dan Zamri, 2011). Terjadinya penurunan tingkat kekerasan cokelat selama dikonsumsi disebabkan oleh cokelat yang mulai meleleh di dalam mulut. Ziegler et al. (2001) menyatakan bahwa proses cokelat meleleh di dalam mulut disebabkan karakteristik lemak sebagai fase kontinyu yang akan mulai meleleh akibat temperature atau panas tubuh. Temperatur yang berhubungan dengan proses transisi seperti pelelehan, akan mengubah struktur suatu bahan pangan selama proses pengunyahan karena selama proses ini suhu akan memulai proses modifikasi makanan yang akan mengubah persepsi tekstur selama proses oral (Pascua et al., 2013).

Faktor yang dapat mempengaruhi baik tidaknya produk cokelat yaitu pada penghalusan dan pencampuran bahan yang digunakan 
serta ada tidaknya pengemulsi (Minifie, 1999). Bahan yang tidak halus dan tidak tercampur rata akan menyebabkan tekstur yang kasar. Penambahan polifenol secara umum meningkatkan penerimaan tekstur produk milk chocolate couverture dan analog dengan skor 2,61-3,26 (cukup suka).

\section{Penampakan}

$\begin{array}{rr}\text { Hasil analisis uji } & \text { organoleptik } \\ \text { untuk penampakan } & \text { produk }\end{array}$ menunjukkan adanya peningkatan kesukaan dengan skor 2,53-3,57 (cukup suka) pada milk chocolate couverture dan analog dengan penambahan polifenol.

Tingginya kandungan polifenol dalam biji akan mendorong terjadinya reaksi Maillard dengan bantuan polifenol oksidase yang menghasilkan warna kakao (Puziah, 2005). Perubahan penampakan visual yang sering dijumpai pada produk cokelat adalah fat bloom, yaitu fenomena cokelat dimana sebagian fat meleleh dan muncul ke permukaan sehingga cokelat tampak berwarna putih, tekstur mengeras, dan susah meleleh yang disebabkan oleh perubahan kristalisasi lemak (Becket, 2008).

Perubahan penampakan visual cokelat menjadi lebih terang dapat disebabkan oleh reaksi Maillard antara asam amino dengan gugus gula sukrosa selama proses pemanasan. Daviez dan Labuza (1994) menyatakan bahwa reaksi Maillard awalnya dideskripsikan sebagai reaksi antara gula pereduksi dan asam-asam amino dari protein. Sumber gula pereduksi yang berpotensi untuk mengalami reaksi Maillard adalah dektrosa, fruktosa, sirup jagung tinggi fruktosa, sakarosa, pati jagung, dan maltodekstrin. Sumber gugus amin ($\mathrm{NH} 2$ ) pada produk konfeksioneri yang dapat terlibat dalam reaksi adalah padatan susu, krim, padatan telur, kacang-kacangan, padatan kakao, butter (mengandung sedikit nitrogen), gelatin, dan lesitin.

\section{SIMPULAN}

Hasil penelitian menunjukkan bahwa penambahan polifenol dapat meningkatkan viskositas produk cokelat secara keseluruhan dan menaikkan titik leleh. Sedangkan untuk parameter total lemak, kadar air, dan ALT memenuhi SNI cokelat dan produk cokelat (SNI 4458-1998), yaitu kadar lemak lebih besar dari $31 \%$, kadar air maksimum $2,0 \%$, dan ALT maksimum $1 \times 10^{4}$ koloni/g. Hasil analisis organoleptik menunjukkan adanya peningkatan penerimaan panelis dengan range skor 3,30-3,57 (cukup suka) untuk produk milk cokelat couverture dan analog dengan penambahan polifenol sebagai penambah aroma, rasa, tekstur, dan penampakan cokelat.

\section{DAFTAR PUSTAKA}

1. Abdullah, M. S. dan Zamri, A. I. 2011. Cocoa Butter Substitute of Chocolate by Using Corn Starch/Xanthan Gum/Glycerin Blends and Their Effects on Melting, Rheological and Nutritional Properties. Empowering Science, Technology and Innovation Towards a Better Tomorrow, 26: 339-343.

2. Ackar, D., Landic, K. V., Valek, M., Subaric, D., Milicevic, B., Babic, J., dan Nedic, H. 2013. Cocoa Polyphenols: Can We Consider Cocoa and Chocolate as Potential Functional Food. Journal of Chemistry, 13: 289296.

3. Aditya, M. dan Ariyanti, P. R. 2016. Manfaat Gambir (Uncaria gambir Roxb) sebagai Antioksidan. Majority, 5: 129133.

4. Afoakwa, E. O. 2008. Cocoa and Chocolate Consumption: Are There Aphrodisiac and Other Benefits for Human Health?. South African Journal of Clinical Nutrition, 21(3): 107-113.

5. Afoakwa, E. O. 2010. Chocolate Science and Technology. England: John Wiley \& Sons.

6. Afoakwa, E. O., Paterson, A., dan Fowler, M. 2007. Factor Influencing Rheological and Textural Qualities in Chocolate-A Review. Trends in Food Science \& Technology. 18(6): 290-298.

7. Akra B., Salengke, dan Supratomo. 2012. Pengaruh Penambahan Lesitin dan Suhu Conching Terhadap Sifat 
Reologi Pasta Kakao (Theobroma cacao L.). Jurnal AgriTechno, 5(1).

8. Andrae-Nightingale, L. M., Lee, S. Y., dan Engeseth, N. J. 2009. Textural Changes in Chocolate Characterized by Instrumental and Sensory Techniques. Journal of Texture Studies, 40(4): 427-444.

9. Ardiansyah. 2007. Antimikroba dari Tumbuhan (Bagian Pertama). Diakses dari http://www.beritaiptek.com.zberitaberitaiptek-2007-06-03-ntimikroba-daritumbuhanpertama).shtml.htm.

(Bagian-

10. Becket, S. T. 2008. The Science of Chocolate. Cambridge: The Royal Society of Chemistry.

11. Becket, S. T. 2009. Industrial Chocolate Manufacture and Use. $4^{\text {th }}$ Edition. Wiley-Blackwell Ltd.

12. Crozier, S. J., Preston, A. G., Hurst, J. W., Payne, M. J., Mann, J., Hainly, L., dan Miller, D. L. 2011. Cocoa Seeds are A "Super Fruit": A Comparative Analysis of Various Fruit Powders and Products. Chemistry Central Journal, 5: 1-6.

13. Daviez C. G. A. dan Labuza, T. P. The Maillard Reaction Application to Confectionery Products. Departement of Food Science and Nutrition University of Minnesota. Diakses dari http://citeseerx.ist.psu.edu/viewdoc/dow nload?doi=10.1.1.22.5873\&rep=rep1\&t ype $=$ pdf.

14. Fernandez V, A., Müller, A. J., Sandoval, A. J. 2013. Thermal, Structural and Rheological of Dark Chocolate with Different Composition. Journal Food Engineering, 116(1): 97108.

15. Harrington, W. L. 2011. The Effects of Roasting Time and Temperature on The Antioxidant Capacity of Cocoa from Dominican Republic, Equador, Haiti, Indonesia and Ivory Coast. The University of Tennessee, Knoxville USA.

16. Indarti, E. A., Normalina, dan Budi S. 2012. Kajian Pembuatan Cokelat Batang dengan Metode Tempering dan Tanpa Tempering. Jurnal Teknologi dan Industri Pertanian Indonesia, 5(1).

17. Jalil, A. M. M. dan Ismail A. 2008. Polyphenols in Cocoa and Cocoa Product: Is There A Link Between Antioxidant Properties and Health?. Molecules, 13: 2190-2219.
18. Jovanovic, O. L. dan Pajin, B. S. 2002. Sensory and instrumental evaluation of physical characteristics of laboratorymade chocolate. Diakses dari http://agris.fao.org/agris-search/ search.do?recordID=YU2003000725

19. Kearsley, M. W. dan Dziedzic, S. Z. 1995. Handbook of Starch Hydrolysis Product and Their Derivatives. Glasgow: Blackie Academic \& Professional.

20. Kelishadi, R. M. D. 2005. Cocoa to Cocoa to Chocolate: Healthy Food?. ARYA Journal, 1: 28-34.

21. Maarse. 1991. Volatile Compounds in Foods and Beverages. New York: Marcel Dekker inc.

22. Minifie, B. W. 1999. Chocolate, Cocoa, and Confectionery: Science and Technology. 3rd Edition. New York: Van Nostrand Reinhold.

23. Nestle Research Centers. 2010. Focus on: Polyphenols in Chocolate. Nestle Research Centers.

24. Pangerang, F. 2012. Pengaruh Penambahan Susu Kedelai dan Gula Berkalori Rendah Untuk Produk Coklat Truffle sebagai Pangan Fungsional. Universitas Hasanudin, Makasar.

25. Pascua, Y., Koç, H., dan Foegeding, E. A. 2013. Food Structure: Roles of Mechanical Properties and Oral Processing in Determining Sensory Texture of Soft Materials. Current Opinion in Colloid and Interface Science, 18(4): 324-333.

26. Puziah, H. S. $2005 . \quad$ Cocoa Fermentation. Jember: Pusat Penelitian Kopi dan Kakao Indonesia.

27. Ramlah, S. dan Sampebarra, L. S. 2018. Karakteristik dan Citarasa Cokelat Putih dari Lemak Kakao Non Deodorisasi dan Deodorisasi. Jurnal Industri Hasil Perkebunan, 13(2): 117128. Balai Besar Industri Hasil Perkebunan, Makassar.

28. Ramlah, S. dan Yumas, M. 2017. Pengaruh Formulasi dan Asal Biji Kakao Fermentasi Terhadap Mutu dan Citarasa Dark Chocolate. Jurnal Industri Hasil Perkebunan.

29. Richard, M. 2018. Industri Mamin Berbasis Cokelat di Indonesia Makin Menjanjikan. Diakses dari http;//mix.co.id/marcomm/brandinsight/marketing-strategy/langkahmondelez-memajukan-pangsa-pasarcokelat. 
30. SNI 4458-1998. SNI Pasta Cokelat. Badan Standarisasi Nasional.

31. SNI 7934-2014. SNI Produk Cokelat. Badan Standarisasi Nasional.

32. Soekarto, S. T. 1985. Penilaian Organoleptik untuk Industri Pangan dan Hasil Pertanian. Jakarta: Bhratara karya Aksara.

33. Sulistyowati dan Misnawi (2008). Effects of Alkali Concentration and Conching Temperature on Antioxidant Activity and Physical Properties of Chocolate. International Food Research Journal, 15: 1-8.

34. Tisoncik, M. A. 2010. Impact of Emulsifier on Physical, Sensory, and Microstructural Properties in Formulated Dark Chocolate with An Innovative Educational Approach. University of Illionis, UrbanaChampaign.
35. Wahyudi. 2008. Panduan Kakao Lengkap, Manajemen Agribisnis dari Hulu hingga Hilir. Jakarta: Penebar Swadaya.

36. Watson, R. R., Preedy, V. R., and Zibadi, S. 2012. Chocolate in Health and Nutrition. New York: Humana Press brand of Springer.

37. Winarno, F. G. 1993. Pangan, Gizi, Teknologi, dan Konsumsi. Jakarta: PT. Gramedia Pustaka Utama.

38. Winarno, F. G. 1997. Kimia Pangan dan Gizi. Jakarta: Gramedia Pustaka Utama.

39. Ziegler, G. R., Mongia, G., dan Hollender, R. 2001. The Role of Particle Size Distribution of Suspended Solids in Defining the Sensory Properties of Milk Chocolate. International Journal of Food Properties, 4(2): 353-370. 